Article

\title{
Selective oxidation of alcohols over nickel zirconium phosphate
}

\author{
Abdol R. Hajipour a,b,*, Hirbod Karimi a,c, Afshin Koohi a \\ a Pharmaceutical Research Laboratory, Department of Chemistry, Isfahan University of Technology, Isfahan 84156, Iran \\ b Department of Neuroscience, University of Wisconsin, Medical School, Madison, WI 53706-1532, USA \\ c Young Researchers and Elite Club, Shahreza Branch, Islamic Azad University, Shahreza, Iran
}

A R T I C L E I N F O

Article history:

Received 15 January 2015

Accepted 10 February 2015

Published 20 July 2015

Keywords:

Nickel zirconium phosphate

Nanoparticle

Alcohol oxidation

Solvent-free

Solid catalyst

\begin{abstract}
A B S T R A C T
Nickel zirconium phosphate nanoparticles were found to function as efficient catalysts for the selective oxidation of a wide range of alcohols to their corresponding ketones and aldehydes using $\mathrm{H}_{2} \mathrm{O}_{2}$ as an oxidizing agent and without any organic solvents, phase transfer catalysts, or additives. The steric and electronic properties of various substrates had significant influence on the reaction conditions required to achieve acetylation. The results showed that this method can be applied for the chemoselective oxidation of benzyl alcohols in the presence of aliphatic alcohols. The catalyst used in the current study was characterized by ICP-OES, XRD, $\mathrm{NH}_{3}-\mathrm{TPD}, \mathrm{Py}-\mathrm{FTIR}, \mathrm{N}_{2}$ adsorption-desorption, SEM and TEM. These analyses revealed that the interlayer distance in the catalyst increased from 0.75 to $0.98 \mathrm{~nm}$ when $\mathrm{Ni}^{2+}$ was intercalated between the layers, whereas the crystallinity of the material was reduced. The nanocatalyst could also be recovered and reused at least seven times without any discernible decrease in its catalytic activity. This new method for the oxidation of alcohols has several key advantages, including mild and environmentally friendly reaction conditions, short reaction time, excellent yields and a facile work-up.
\end{abstract}

(C) 2015, Dalian Institute of Chemical Physics, Chinese Academy of Sciences. Published by Elsevier B.V. All rights reserved.

\section{Introduction}

$\alpha$-Zirconium phosphate (ZP) is one of the most important compounds in inorganic chemistry, and the layered structure of this material has led to its use in a variety of different fields [1-3]. ZP behaves as a unique ion exchanger because of its exceptionally poor aqueous solubility, high thermal stability, resistance to radiation and abrasive properties [4,5]. The $\mathrm{H}^{+}$of the $\mathrm{P}-\mathrm{OH}$ moiety in $\mathrm{ZP}$ can be exchanged for various ions, resulting in an enlargement of the interlayer distance [6-9]. Several studies pertaining to the successful exchange of this proton with various divalent and trivalent cations have been presented in the literature [10-14]. It has also been reported that ZP possesses excellent selectivity towards $\mathrm{Pb}^{2+}, \mathrm{Zn}^{2+}$, and $\mathrm{Fe}^{3+}$ as an ion exchanger [15-17]. Furthermore, ZP has been reported to exhibit antibacterial activity when loaded with $\mathrm{Cu}^{2+}, \mathrm{Zn}^{2+}$, or $\mathrm{Ce}^{3+}[5,6,13,14]$. There have also been several reports concerning the catalytic activity of ion-exchanged materials of this type, including the use of zinc zirconium phosphate (ZPZn) and copper zirconium phosphate (ZPCu) as catalysts in the acetylation of alcohols and phenols and the use of potassium iron zirconium phosphate as a catalyst in Friedel-Crafts benzoylation reactions [18-24].

The selective oxidation of alcohols into the corresponding carbonyl compounds is of importance in research because the corresponding aldehydes, ketones and carboxylic derivatives serve as important and versatile intermediates for the synthesis of various chemicals, vitamins, drugs and fragrances [25-27]. For example, benzaldehyde (BzH) is a typical product of alcohol oxidation and a starting material for the preparation

\footnotetext{
* Corresponding author. Tel: +98-0311-3913262; Fax: +98-0311-3913252; E-mail: haji@cc.iut.ac.ir 
of intermediates for dyestuffs, agrochemicals, perfumery and pharmaceuticals [27-29]. From economic and environmental viewpoints, there have been many recent publications emphasizing environmentally benign methods for the oxidation of alcohols, using molecular $\mathrm{O}_{2}$ or aqueous $\mathrm{H}_{2} \mathrm{O}_{2}$ as the oxidant, in the presence and/or absence of solvents such as $\mathrm{CuSO}_{4}$ [25], $\mathrm{CuBr}_{2}$ [26], AMPA [28], MPA/ $\mathrm{V}_{2} \mathrm{O}_{5}-\mathrm{Al}_{2} \mathrm{O}_{3}$ [29], TEMPO-IL/CuCl [30], $\mathrm{Ni}_{3}\left[\mathrm{Fe}(\mathrm{CN})_{6}\right]_{2}$ [31], (Pd/Fe@C) [32], silica-gel-TEMPO-NO ${ }_{x}$ [33], CoTM4PyP-MT [34], $\mathrm{Zn}_{4}\left(\mathrm{P}_{2} \mathrm{~W}_{15} \mathrm{O}_{56}\right)^{16-} \quad$ [35], (TEAH) $\mathrm{H}_{2} \mathrm{PW}_{12} \mathrm{O}_{40}$ [36], $\mathrm{Zn-Co-LDH} \mathrm{[37],} \mathrm{RuCl}_{3} \cdot 3 \mathrm{H}_{2} \mathrm{O}$ [38], $\mathrm{H}_{4} \mathrm{SiW}_{12} \mathrm{O}_{40} / \mathrm{SiO}_{2}$ [39], AuRu/AC [40], oxidovanadium(V) complexes [41], Ag/SBA-15 [42], DHPDMDO [43], $\mathrm{H}_{2} \mathrm{WO}_{4} /\left[\mathrm{C}_{8} \mathrm{mim}\right]\left[\mathrm{NTf}_{2}\right]$ [44], SF-3-APTS-Fe(TCIPP) [45], Na$\mathrm{BrO}_{3} /[\mathrm{bmim}] \mathrm{Br}$ [46], KBr/Oxone [47], WO $\mathrm{WPMO}_{4} @ \mathrm{PL}$ [48], $\mathrm{Cu}$-NHC-TEMPO complexes [49], $\mathrm{Cu} / \mathrm{AlO}(\mathrm{OH})_{x}$ [50], $\mathrm{Na}_{4} \mathrm{H}_{3}$ $\left[\mathrm{SiW}_{9} \mathrm{Al}_{3} \cdot\left(\mathrm{H}_{2} \mathrm{O}\right) \cdot 3 \mathrm{O}_{37}\right]$ [51], copper/imidazolium/TEMPO [52], $\mathrm{Ca}(\mathrm{ClO})_{2} / \mathrm{Al}_{2} \mathrm{O}_{3}$ [53], PVPTB [54], Au/UiO-66 [55], PSFC [56], $\mathrm{Au} / \mathrm{Al}_{2} \mathrm{O}_{3}$ [57], $\mathrm{PMo}{ }_{11} \mathrm{M}(\mathrm{M}=\mathrm{Co}, \mathrm{Mn}, \mathrm{Ni})$ [58], Mn(salen)OAc [59], BPFC [60], $\mathrm{KMnO}_{4}$-aluminum silicate [61], MnTPPS-silica [62] and $\mathrm{PVP}-\mathrm{H}_{2} \mathrm{O}_{2}$ [63]. Homogeneous catalysts have drawbacks in terms of their corrosive nature, pollution of the product with catalyst, tedious catalyst separation and post-synthesis disposals, and recovery from the effluents. However, the design of a new catalyst, which gives excellent conversion with maximum selectivity for organic transformation, is one of the challenges in the field of catalysis. With growing environmental concerns, one of the most promising ways to achieve these goals seems to be the use of green and insoluble catalysts or of ecofriendly solvent-free conditions. $\mathrm{H}_{2} \mathrm{O}_{2}$ is a green and very clean oxidant for liquid phase oxidations because it provides a high content of active oxygen species where water is the only byproduct. This oxidant is much cheaper and safer than most other organic and inorganic oxidants and is also readily available. When an insoluble catalyst is used, it can be easily recovered from the reaction mixture by simple filtration and recycled and can be reused several times, making the process more economically and environmentally viable. Furthermore, reported examples have demonstrated that heterogeneous catalysts typically require easier work-up procedures. With this in mind, and as part of ongoing work towards the development of efficient green catalysts for organic transformations [64,65] with particular emphasis on the oxidation of alcohols [23], we report herein the use of nickel zirconium phosphate (ZPNi) as an efficient catalyst for the mild and convenient selective oxidation of alcohols as characterized by ICP-OES, XRD, BET, $\mathrm{NH}_{3}$-TPD, Py-FTIR, SEM and TEM.

\section{Experimental}

\subsection{Catalyst synthesis}

All the reagents and solvents used in the current study were purchased from Merck Chemical Company and used without further purification. The catalyst was prepared according to previously published procedures, with minor modifications [2,8-10]. As an initial step, ZP was prepared according to the following procedure. $\mathrm{ZrOCl}_{2} \cdot 8 \mathrm{H}_{2} \mathrm{O}(5 \mathrm{~g})$ was heated at reflux in a solution of $\mathrm{H}_{3} \mathrm{PO}_{4}(50 \mathrm{~mL}, 12 \mathrm{~mol} / \mathrm{L})$ for $24 \mathrm{~h}$. The resulting mixture was cooled to ambient temperature to give a suspension, which was filtered and then washed with a solution of $\mathrm{H}_{3} \mathrm{PO}_{4}(0.1 \mathrm{~mol} / \mathrm{L})$ until the filtrate was free of chloride ions. The filter cake was then washed several times with distilled water until the $\mathrm{pH}$ of the filtrate was neutral. The solid was collected and dried in an oven at $110^{\circ} \mathrm{C}$ for $24 \mathrm{~h}$.

ZPNi was prepared through an ion exchange reaction [8-10]. Briefly, ZP (3 g) was dispersed in deionized water (50 $\mathrm{mL}$ ) at $50{ }^{\circ} \mathrm{C}$ and the resulting suspension was treated with a solution of $\mathrm{Ni}(\mathrm{OAc})_{2}(100 \mathrm{~mL}, 0.1 \mathrm{~mol} / \mathrm{L})$ in water (excess amount of $\mathrm{Ni}^{2+}$ ). This mixture was then heated at reflux for $4 \mathrm{~d}$. It is noteworthy that the acetate ion performed effectively as a base to keep the hydrogen ion concentration in solution sufficiently low to achieve high loadings of the catalyst [24]. A complete exchange between the cations and the hydrogen ions of the $\mathrm{P}-\mathrm{OH}$ groups could not be achieved in less than $3 \mathrm{~d}$ or at temperatures below $80{ }^{\circ} \mathrm{C}$ [13]. The resulting slurry was filtered hot to give a light green solid, which was washed with distilled water until no $\mathrm{Ni}^{2+}$ ions could be detected in the filtrate (i.e., until the filtrate was colorless). The solid product was then dried at $100{ }^{\circ} \mathrm{C}$ for $24 \mathrm{~h}$ before being calcined at $600{ }^{\circ} \mathrm{C}$ for $4 \mathrm{~h}$ to give the final product, $\mathrm{ZPNi}$, as a pale green solid (Scheme 1).

\subsection{Catalyst characterization}

The chemical composition of the ZPNi catalyst was evaluated at different stages of the reaction (i.e., before and after the catalytic reaction) using an Optima $7300 \mathrm{~V}$ ICP-OES spectrometer (PerkinElmer). The samples were ground into a fine powder and analyzed by XRD on a Philips X'pert X-ray diffractometer. The specific surface areas of the samples were determined from their $\mathrm{N}_{2}$ adsorption-desorption isotherms using the Brunauer-Emmett-Teller (BET) method on a Quantachrome ChemBET 3000 instrument. Each sample was degassed at 400 ${ }^{\circ} \mathrm{C}$ for $2 \mathrm{~h}$ before being analyzed to remove any adsorbed species from their surfaces. The BET surface areas of the materials were estimated from their $\mathrm{N}_{2}$ adsorption-desorption isotherms. The surface morphologies of the ZP and ZPNi materials were studied by SEM on a Philips XL scanning electron microscope (Philips). TEM images of ZPNi were obtained on a CENTRA 100 TEM system (Zeiss).

\subsection{General experimental procedure for the oxidation reaction}

ZPNi (0.5 mol\%) was added to $5-\mathrm{mmol}$ substrate in a $25-\mathrm{mL}$ two-necked flask. The mixture was heated in an oil bath to 50

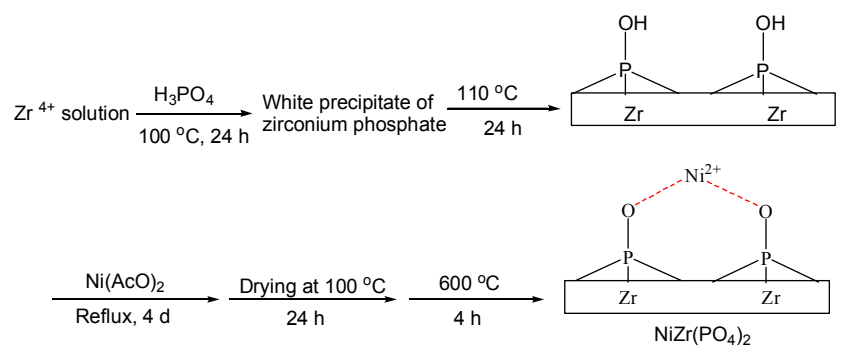

Scheme 1. Procedure for the preparation of ZPNi. 
${ }^{\circ} \mathrm{C}$ and $30 \% \mathrm{H}_{2} \mathrm{O}_{2}$ (0.015 mol) was added slowly with continuous stirring for the specified time. The reaction progress was monitored by GC. At the end of the reaction, the mixture was cooled to room temperature and the catalyst was removed from the reaction mixture by centrifugation. Afterwards, the organic layer was separated from the aqueous phase by extraction with $\mathrm{n}$-hexane and drying over anhydrous $\mathrm{CaCl}_{2}$. The identities of reaction products were confirmed by FT-IR, GC-MS and $1 \mathrm{H}$ NMR.

\subsection{Recyclability studies of catalyst}

To examine the recyclability of the catalyst, the used ZPNi was recovered from the reaction media and reused. After the first use, the catalyst was separated from the reaction mixture by centrifugation, washed sequentially with ethanol and water before being dried at $110{ }^{\circ} \mathrm{C}$ for $2 \mathrm{~h}$, and then activated at 450 ${ }^{\circ} \mathrm{C}$ for $2 \mathrm{~h}$.

\section{Results and discussion}

\subsection{Catalyst characterization results}

The ICP-OES analyses of ZP and ZPNi are shown in Table 1. The results obtained in the current study for ZPNi were compared with those reported previously in the literature [8-10]. Our results revealed that there was a negligible leach of nickel ions into the reaction media after the reaction (i.e., following the first use of the catalyst).

Figure 1 shows the powder XRD patterns of the ZP and ZPNi materials. The results show some characteristic reflections in the $2 \theta$ range of $5^{\circ}-40^{\circ}$. The diffraction peak in $\mathrm{ZP}$ at $2 \theta \approx 12^{\circ}$ was assigned to a $d_{002}$ basal spacing of $0.75 \mathrm{~nm}$ between the planes, which was consistent with the patterns previously reported for ZP and its derivatives with a hexagonal crystal system [2]. It shows that the $d$-spacing of the (002) plane of ZPNi had increased, which indicated that the $\mathrm{Ni}^{2+}$ ions had intercalated into the interlayer of ZP and increased the $\mathrm{d}_{002}$ basal interlamellar spacing of ZP from 0.75 to $0.98 \mathrm{~nm}$. It is well known that the ion radii of $\mathrm{Ni}^{2+}(0.069 \mathrm{~nm})$ and hydrated $\mathrm{Ni}^{2+}(0.404$ $\mathrm{nm})$ are smaller than the basal spacing of ZP $(0.75 \mathrm{~nm})[66,67]$.

The XRD results indicated that $\mathrm{Ni}^{2+}$ ions had inserted into the interlayer of ZP and increased the basal spacing of the modified ZP after the exchange [8-10]. These data indicated that ZPNi had been formed successfully. The XRD pattern of the ZPNi catalyst after the 8th run showed that the basal spacing of ZP was about $1.03 \mathrm{~nm}$, which was only a little larger than that

Table 1

Elemental content (atom\%) of ZPNi and physical properties of catalysts before and after reaction.

\begin{tabular}{lcccccc}
\hline Sample & $\mathrm{Ni}$ & $\mathrm{O}$ & $\mathrm{Zr}$ & $\mathrm{P}$ & $\begin{array}{c}\mathrm{BET} \\
\left(\mathrm{m}^{2} / \mathrm{g}\right)\end{array}$ & $\begin{array}{c}\text { Total acidity } \\
\left(\mathrm{mmol} \mathrm{NH}_{3} / \mathrm{g}\right)\end{array}$ \\
\hline $\mathrm{ZP}$ & - & 63.1 & 13.6 & 23.3 & 132.8 & 2.6 \\
$\mathrm{ZPNi}$ & 10.2 & 59.2 & 11.4 & 19.2 & 121.5 & 1.8 \\
$\mathrm{ZPNi}^{\mathrm{a}}$ & 10.0 & 58.8 & 11.7 & 19.5 & 120.7 & 1.63 \\
ZPNi $^{\mathrm{b}}$ & 4.4 & 62.8 & 13.0 & 19.8 & 72.3 & 0.58 \\
\hline
\end{tabular}

a After the first cycle.

b After the 8th cycle.

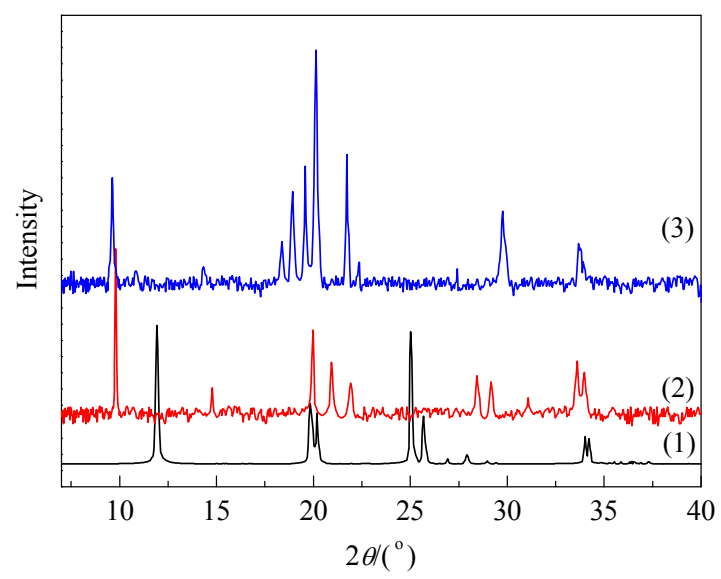

Fig. 1. XRD patterns of powder ZP (1), fresh ZPNi (2) and ZPNi after the 8th run (3).

of the fresh ZPNi catalyst. This increase may have occurred because of a decrease in $\mathrm{Ni}^{2+}$ on the surface of $\mathrm{ZP}$, and an increase in the number of water molecules between the layers following the seventh run (i.e., $\mathrm{Ni}^{2+}$ ions may have been washed off during the regeneration of the catalyst, section 2.3 and Table 1).

Figure 2 shows the $\mathrm{N}_{2}$ adsorption-desorption isotherm of $\mathrm{ZPNi}$ as a representative example in the relative pressure range $\left(p / p_{0}\right)$ of $0.1-1.0$. The surface area of ZPNi was determined to be $121.5 \mathrm{~m}^{2} / \mathrm{g}$. The isotherm for ZPNi shows three adsorption stages. The first of these stages was observed at $p / p_{0}<0.37$, whereas the second stage was observed in the range of $0.37<$ $p / p_{0}<0.93$, and the third stage was observed at higher relative pressures $\left(p / p_{0}>0.93\right)$. The $\mathrm{N}_{2}$ adsorption-desorption isotherm of ZPNi exhibited a typical "type IV" isotherm shape with a distinct hysteresis loop that is characteristic of a mesoporous material [68]. The hysteresis loop (type H3) is associated with the occurrence of capillary condensation in the mesopores and indicates the presence of a mesoporous structure in the $\mathrm{ZPNi}$ catalyst. The observed increase in adsorption at the higher $p / p_{0}$ value indicated the presence of larger mesopores in the sample [9]. The surface area of ZPNi after the 8th run was found to be $72.3 \mathrm{~m}^{2} / \mathrm{g}$.

Pyridine adsorption was used to determine the acidic sites

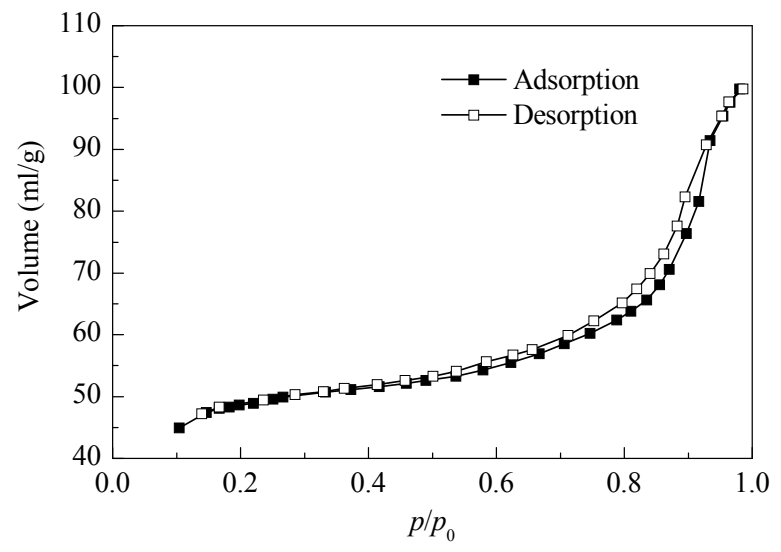

Fig. 2. $\mathrm{N}_{2}$ adsorption-desorption isotherm of ZPNi. 


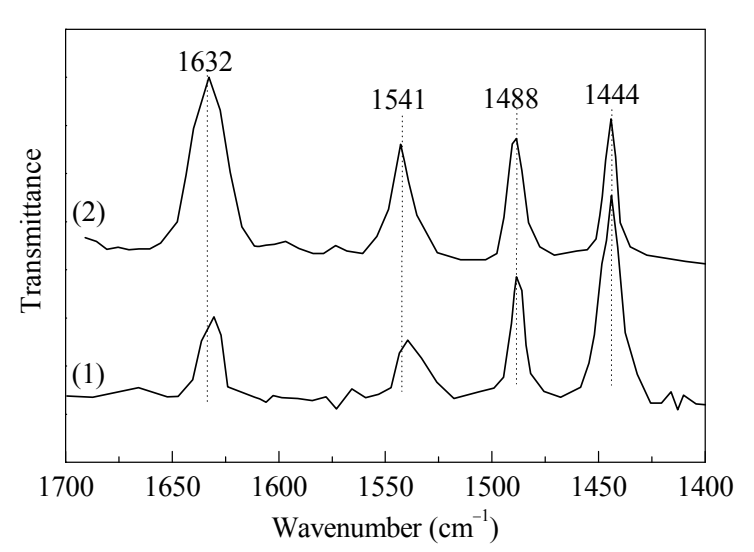

Fig. 3. Pyridine-desorbed FTIR spectra of the calcined ZPNi. (1) Fresh; (2) After the 8th run.

using FTIR. Prior to the measurements, $20 \mathrm{mg}$ of a catalyst was pressed into a self-supporting disc and activated in the IR cell attached to a vacuum line at $350{ }^{\circ} \mathrm{C}$ for $4 \mathrm{~h}$. The adsorption of pyridine was performed at $150{ }^{\circ} \mathrm{C}$ for $30 \mathrm{~min}$. The excess of probe molecules was further evacuated at $150{ }^{\circ} \mathrm{C}$ for $30 \mathrm{~min}$. The adsorption-evacuation was repeated several times until no changes in the spectra were observed (Fig. 3(1)).

The main bands observed over the samples are assigned according to the literature data $[69,70]$. The pyridine-desorbed FTIR spectra of ZPNi shows strong bands at 1632 and 1541 $\mathrm{cm}^{-1}$, indicating the presence of the pyridinium ion. The band at $1488 \mathrm{~cm}^{-1}$ is a combination band between those at 1541 and $1444 \mathrm{~cm}^{-1}$ and correspond to Brönsted and Lewis acid sites, respectively [18].

Figure 3(2) shows the Py-FTIR spectrum of the catalyst after the 8 th run. It clearly indicates that the replacement of $\mathrm{Ni}^{2+}$ on the surface of the catalyst with $\mathrm{H}^{+}$during the catalyst regeneration process has reduced the number of Lewis acid sites (band at $1444 \mathrm{~cm}^{-1}$ was reduced). Conversely, the amount of Bronsted acid sites were increased (band at $1632 \mathrm{~cm}^{-1}$ was reduced).

The total acidity of samples were determined by temperature-programmed desorption of ammonia (NH3-TPD) with a Quantachrome ChemBET 3000. Before the adsorption of ammonia, the samples were pre-treated in $\mathrm{He}$ at $250^{\circ} \mathrm{C}$ for $30 \mathrm{~min}$ followed by $1 \mathrm{~h}$ at $350{ }^{\circ} \mathrm{C}$ and then cooled to $100{ }^{\circ} \mathrm{C}$. Ammonia was then adsorbed onto the samples for $1 \mathrm{~h}$. The $\mathrm{NH}_{3}$-TPD was carried out between 150 and $550{ }^{\circ} \mathrm{C}$, at $10{ }^{\circ} \mathrm{C} / \mathrm{min}$, and analyzed by a thermal conductivity detector (TCD) for continuous monitoring of the desorbed ammonia. $\mathrm{NH}_{3}$-TPD provides a quantitative estimation of the total number of acid sites and the distribution of acid strengths. Because of the strong basicity of $\mathrm{NH}_{3}$ gas, it was expected that all acid sites on the catalysts would interact with $\mathrm{NH}_{3}$. The total amount of $\mathrm{NH}_{3}$ desorbed after saturation permits the quantification of the number of acid sites on the surface, while the position of the peak and the desorption temperature indicates the strength of the catalyst, i.e., the higher temperature of desorption, the stronger the acid strength [64]. The $\mathrm{NH}_{3}$-TPD curves of ZPNi are shown in Fig. 4.

ZPNi desorbed ammonia at a wide range of temperatures from 212 to $538{ }^{\circ} \mathrm{C}$, which mostly corresponds to the medium

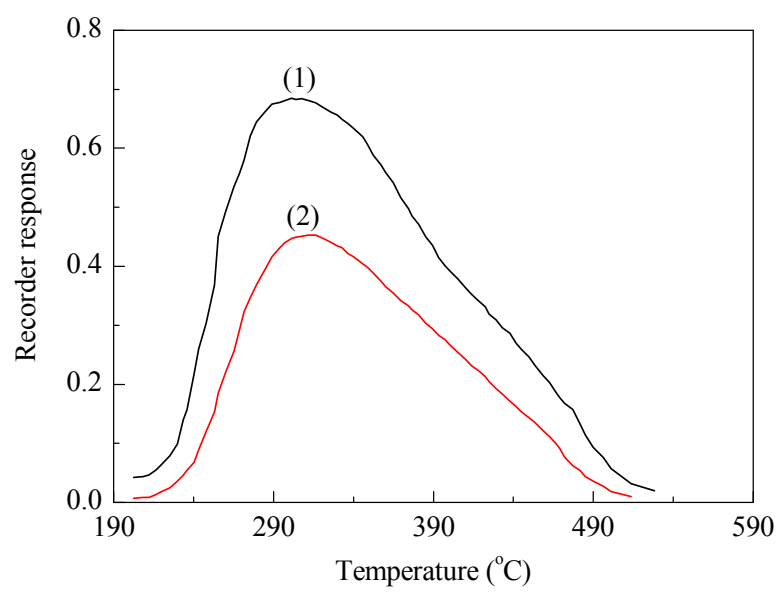

Fig. 4. $\mathrm{NH}_{3}$-TPD profile of ZPNi. (1) Fresh; (2) After the 8th run.

and strong acidic sites. $\mathrm{The}^{\mathrm{NH}_{3}}$ desorption peak at temperatures below $250{ }^{\circ} \mathrm{C}$ belongs to the physisorption/chemisorption of $\mathrm{NH}_{3}$ molecules on weak acidic sites. The peak at about $250-450{ }^{\circ} \mathrm{C}$ shows the existence of intermediate strength acidic sites while the peak at $450-538{ }^{\circ} \mathrm{C}$ demonstrates the presence of strong acidic sites on the surface of ZPNi. Figure 4 shows that the desorption of ammonia starts at almost $212{ }^{\circ} \mathrm{C}$ and peaks at $317^{\circ} \mathrm{C}$. The $\mathrm{NH}_{3}$-TPD curves decreased with further increases in temperature and were almost complete at $538^{\circ} \mathrm{C}$.

Figure 4 indicates that ZPNi contains a considerable number of acidic sites owing to the presence of $\mathrm{Ni}^{2+}$ groups on the surface of ZP layers making it suitable as a solid acid catalyst. The extent of desorption is found to be ca. $1.8 \mathrm{mmol} / \mathrm{g}$ for the catalyst. A TPD experiment was carried out after the 8th cycle on recovered catalyst to compare with fresh catalyst (Table 1).

The SEM image of ZP (Figure 5(a)) revealed the presence of hexagonal plates with well-defined shapes and very smooth surfaces. Figures 5(b) and (c) show the SEM images of ZPNi. These images revealed that the structure of ZPNi was much less ordered than that of ZP, and that the ZPNi particles had aggregated to form both sheets and spheres of different shapes and sizes $[4,9]$.

Figure 6 shows the TEM images of ZPNi. It shows that ZPNi

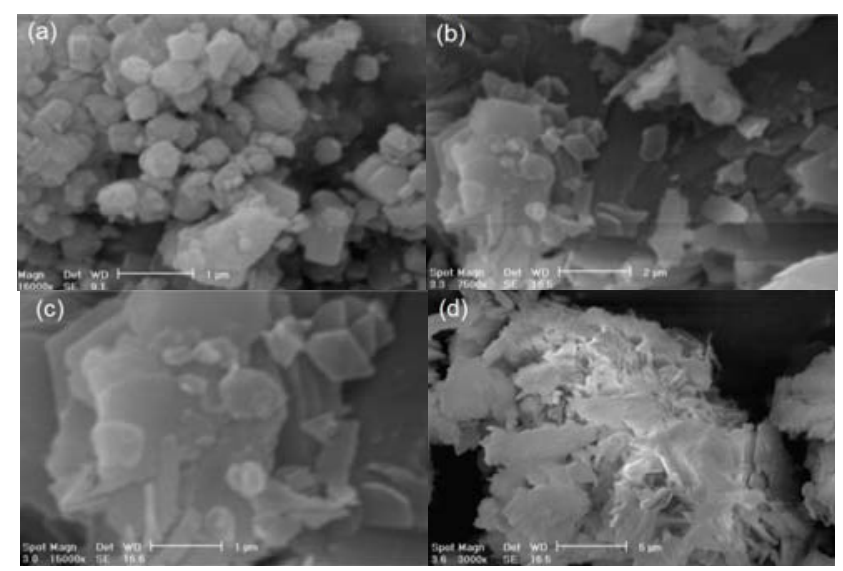

Fig. 5. SEM images of prepared ZP (a), fresh ZPNi (b, c) and ZPNi after the 8 th run $(d)$. 


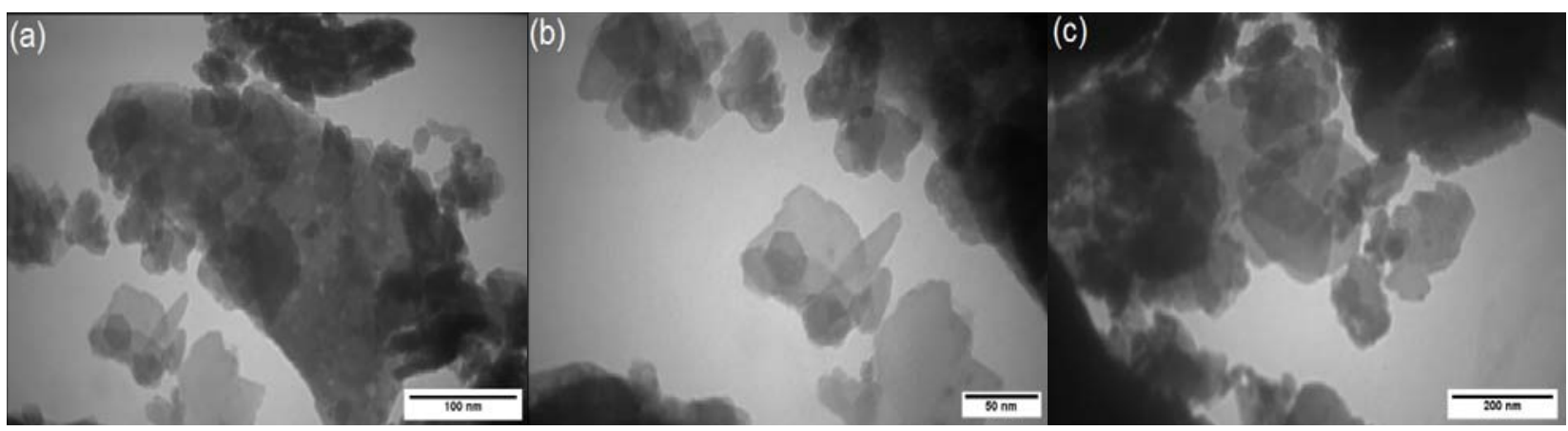

Fig. 6. TEM images of fresh ZPNi (a, b) (different magnification) and after the 8th run (c).

catalyst retained the original morphology of ZP (layered structure) and that the particles were approximately $150 \mathrm{~nm}$ in size. These images also showed nanoparticles of different size on the smooth surface of the ZP. The presence of metallic crystal nanoparticles on the surface of ZP indicated that the nickel deposited on the surface of the ZP had agglomerated. Similar observations have also been reported for zinc, copper and cerium with ZP $[6,14,24]$.

Figures 5(d) and 6(c) show SEM and TEM images, respectively, of the catalyst following its 8th run. Both of these images showed that the sheets and particles had conglomerated to a much greater extent following the 8th run because of the process used to regenerate the catalyst.

\subsection{Oxidation reaction and expected mechanism}

Initially, the benzyl alcohol (BzOH) was selected as the model substrate to determine the optimal conditions. The results are summarized in Table 2. Although the major product was $\mathrm{BzH}$, benzoic acid was also formed as a side product (Table

Table 2

Oxidation conditions of benzyl alcohol (BzOH).

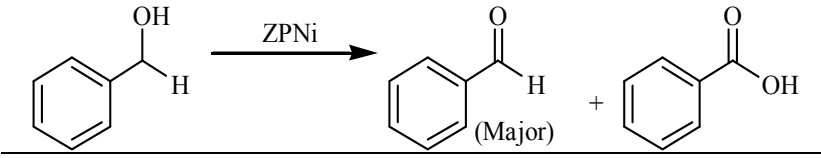

\begin{tabular}{lcccccc}
\hline Entry & $\begin{array}{c}\text { Time } \\
\text { (min) }\end{array}$ & $\begin{array}{c}\mathrm{BzOH}: \mathrm{H}_{2} \mathrm{O}_{2} \\
\text { mole ratio }\end{array}$ & $\begin{array}{c}\text { Temper- } \\
\text { ature }\left({ }^{\circ} \mathrm{C}\right)\end{array}$ & $\begin{array}{c}\text { Catalyst } \\
(\mathrm{mol} \%)\end{array}$ & $\begin{array}{c}\text { Isolated } \\
\text { yield a }(\%)\end{array}$ & $\begin{array}{c}\text { Selectivity a } \\
(\%)\end{array}$ \\
\hline 1 & 5 & $1: 3$ & 50 & 0.5 & 56 & $>99$ \\
2 & 10 & $1: 3$ & 50 & 0.5 & 71 & $>99$ \\
3 & 15 & $1: 3$ & 50 & 0.5 & 90 & $>99$ \\
4 & 20 & $1: 3$ & 50 & 0.5 & $83(90)$ & $70(30)$ \\
5 & 25 & $1: 3$ & 50 & 0.5 & $75(91)$ & $62(38)$ \\
6 & 15 & $1: 1$ & 50 & 0.5 & 50 & $>99$ \\
7 & 15 & $1: 2$ & 50 & 0.5 & 70 & $>99$ \\
8 & 15 & $1: 4$ & 50 & 0.5 & $90(91)$ & $80(20)$ \\
9 & 90 & $1: 3$ & $25(30)$ & 0.5 & 20 & $>99$ \\
10 & 90 & $1: 3$ & 40 & 0.5 & 75 & $>99$ \\
11 & 15 & $1: 3$ & 60 & 0.5 & $87(84)$ & $73(27)$ \\
12 & 15 & $1: 3$ & 50 & 0.1 & 48 & $>99$ \\
13 & 15 & $1: 3$ & 50 & 0.25 & 62 & $>99$ \\
14 & 15 & $1: 3$ & 50 & 0.75 & $80(82)$ & $75(25)$ \\
15 & 15 & $1: 3$ & 50 & 1.0 & $76(90)$ & $67(33)$ \\
16 & 120 & $1: 3$ & 50 & - & - & - \\
$17 \mathrm{~b}$ & 120 & $1: 3$ & 50 & 0.5 & 3 & $>99$ \\
\hline
\end{tabular}

a The number in the "( )" was the selectivity or yield of benzoic acid. $\mathrm{b} \mathrm{ZP}$ was used as the catalyst.
2 , entries $4,5,8,11,14,15)$. It was found that by changing reaction parameters, such as time (Table 2 , entries $1-5$ ), mole ratio (Table 2, entries 6-8), temperature (Table 2, entries 9-11) and catalyst amount (Table 2, entries 12-15), the selectivity and/or yield were changed.

As can be seen from Table 2, increase in the reaction time up to $15 \mathrm{~min}$ increase the yield of $\mathrm{BzH}$ where it is also the only product. However, at longer reaction time, benzoic acid was produced as a byproduct and the $\mathrm{BzH}$ yield was reduced to $75 \%$. When the mole ratio of $\mathrm{BzOH}: \mathrm{H}_{2} \mathrm{O}_{2}$ reached $1: 3$, the highest yield was obtained. Further increases in the $\mathrm{BzOH}: \mathrm{H}_{2} \mathrm{O}_{2}$ mole ratio slightly increased the yield but sharply decreased selectivity towards BzH (Table 2, entries 2, 6-8). The optimum reaction temperature for the oxidation of $\mathrm{BzOH}$ was determined by performing the reaction at different temperatures. The yield of BzH was very low at room temperature even after 90 min (Table 2, entry 9). Table 2 shows that increases in temperature up to a maximum temperature of $50{ }^{\circ} \mathrm{C}$ can accelerate the reaction. However, further temperature increases result in a decrease in the yield, which might be owing to the over-oxidation of BzH to benzoic acid or the self-decomposition of $\mathrm{H}_{2} \mathrm{O}_{2}$ at higher temperatures leading to insufficient oxidation of $\mathrm{BzOH}$ (Table 2, entries 2, 9-11). Hence, the best results were achieved when the reaction was performed with a $\mathrm{BzOH}: \mathrm{H}_{2} \mathrm{O}_{2}$ mole ratio of $1: 3$ at $50{ }^{\circ} \mathrm{C}$ for 15 min (Table 2, entry 2). To evaluate the role of our catalyst, the oxidation reaction was performed with ZP used as the catalyst for comparison (Table 2, entry 17). The oxidation reaction was also performed in the absence of catalysts (Table 2, entry 16). No significant amount of $\mathrm{BzH}$ was detected indicating that $\mathrm{H}_{2} \mathrm{O}_{2}$ alone is unable to oxidize $\mathrm{BzOH}$ to $\mathrm{BzH}$.

As shown in Table 3, a wide range of alcohols bearing either electron-donating or electron-drawing groups were successfully oxidized into their corresponding carbonyl compounds within short reaction time. Notably, the efficient transformations of primary alcohols into the desired aldehydes were observed without any over-oxidation to the corresponding carboxylic acid (Table 3, entries 1-14). Both electron-donating and electron-drawing groups accelerated the oxidation reaction, but ortho-substituted substrates (Table 3, entries 2, 5, 7, 9) gave relatively lower yields compared with the corresponding para-isomer because of steric hindrance [26,50,52]. Compared with benzylic alcohols, aliphatic alcohols showed relatively low reactivity toward oxidation (Table 3, entries 22-25). 
Table 3

The oxidation reaction in the presence of ZPNi.

\begin{tabular}{|c|c|c|c|c|c|c|}
\hline Entry & $\mathrm{R}_{1}$ & $\mathrm{R}_{2}$ & $\begin{array}{l}\text { Time } \\
\text { (min) }\end{array}$ & $\begin{array}{l}\text { Mole } \\
\text { ratio }^{a}\end{array}$ & $\begin{array}{c}\text { Isolated } \\
\text { yield (\%) }\end{array}$ & $\begin{array}{c}\text { Selectivity } \\
(\%)\end{array}$ \\
\hline 1 & $\mathrm{Ph}$ & $\mathrm{H}$ & 15 & $1: 3$ & 90 & $>99$ \\
\hline 2 & $2-\mathrm{MeO}-\mathrm{C}_{6} \mathrm{H}_{4}$ & $\mathrm{H}$ & 10 & $1: 3$ & 82 & $>99$ \\
\hline 3 & $4-\mathrm{MeO}-\mathrm{C}_{6} \mathrm{H}_{4}$ & $\mathrm{H}$ & 10 & $1: 3$ & 95 & $>99$ \\
\hline 4 & 4-Me- $\mathrm{C}_{6} \mathrm{H}_{4}$ & $\mathrm{H}$ & 10 & $1: 3$ & 91 & $>99$ \\
\hline 5 & $2-\mathrm{Cl}-\mathrm{C}_{6} \mathrm{H}_{4}$ & $\mathrm{H}$ & 10 & $1: 3$ & 87 & $>99$ \\
\hline 6 & $4-\mathrm{Cl}-\mathrm{C}_{6} \mathrm{H}_{4}$ & $\mathrm{H}$ & 10 & $1: 3$ & 95 & $>99$ \\
\hline 7 & $2-\mathrm{Br}-\mathrm{C}_{6} \mathrm{H}_{4}$ & $\mathrm{H}$ & 10 & $1: 3$ & 83 & $>99$ \\
\hline 8 & $4-\mathrm{Br}-\mathrm{C}_{6} \mathrm{H}_{4}$ & $\mathrm{H}$ & 10 & $1: 3$ & 95 & $>99$ \\
\hline 9 & $2-\mathrm{NO}_{2}-\mathrm{C}_{6} \mathrm{H}_{4}$ & $\mathrm{H}$ & 10 & $1: 3$ & 87 & $>99$ \\
\hline 10 & $4-\mathrm{NO}_{2}-\mathrm{C}_{6} \mathrm{H}_{4}$ & $\mathrm{H}$ & 10 & $1: 3$ & 95 & $>99$ \\
\hline 11 & 4-NC- $\mathrm{C}_{6} \mathrm{H}_{4}$ & $\mathrm{H}$ & 10 & $1: 3$ & 95 & $>99$ \\
\hline 12 & 1-Naphthyl & $\mathrm{H}$ & 10 & $1: 3$ & 90 & $>99$ \\
\hline 13 & 2-Naphthyl & $\mathrm{H}$ & 10 & $1: 3$ & 93 & $>99$ \\
\hline 14 & $\mathrm{PhCH}=\mathrm{CH}$ & $\mathrm{H}$ & 10 & $1: 3$ & 92 & $>99$ \\
\hline 15 & $\mathrm{Ph}$ & $\mathrm{Ph}$ & 60 & $1: 3$ & 81 & $>99$ \\
\hline 16 & $\mathrm{Ph}$ & $\mathrm{CH}_{3}$ & 60 & $1: 3$ & 84 & $>99$ \\
\hline 17 & $4-\mathrm{MeO}-\mathrm{C}_{6} \mathrm{H}_{4}$ & $\mathrm{CH}_{3}$ & 45 & $1: 3$ & 87 & $>99$ \\
\hline 18 & 4-Me- $\mathrm{C}_{6} \mathrm{H}_{4}$ & $\mathrm{CH}_{3}$ & 45 & $1: 3$ & 83 & $>99$ \\
\hline 19 & $4-\mathrm{Cl}-\mathrm{C}_{6} \mathrm{H}_{4}$ & $\mathrm{CH}_{3}$ & 45 & $1: 3$ & 86 & $>99$ \\
\hline 20 & $4-\mathrm{Br}-\mathrm{C}_{6} \mathrm{H}_{4}$ & $\mathrm{CH}_{3}$ & 45 & $1: 3$ & 89 & $>99$ \\
\hline 21 & $4-\mathrm{NO}_{2}-\mathrm{C}_{6} \mathrm{H}_{4}$ & $\mathrm{CH}_{3}$ & 45 & $1: 3$ & 91 & $>99$ \\
\hline 22 & $\mathrm{CH}_{3} \mathrm{CH}_{2} \mathrm{CH}_{2}$ & $\mathrm{H}$ & 90 & $1: 4$ & 80 & $>99$ \\
\hline 23 & $\mathrm{CH}_{3} \mathrm{CH}_{2}$ & $\mathrm{CH}_{3}$ & 90 & $1: 4$ & 71 & $>99$ \\
\hline 24 & $\mathrm{CH}_{3}\left(\mathrm{CH}_{2}\right)_{4}$ & $\mathrm{H}$ & 90 & $1: 4$ & 78 & $>99$ \\
\hline 25 & Cyclohexanol & - & 90 & $1: 4$ & 70 & $>99$ \\
\hline $26^{b}$ & $\mathrm{Ph}$ & $\mathrm{H}$ & 20 & $1: 3$ & 86 & $>99$ \\
\hline 27 & $\mathrm{CH}_{3}\left(\mathrm{CH}_{2}\right)_{4}$ & $\mathrm{H}$ & 20 & $1: 3$ & 5 & $>99$ \\
\hline
\end{tabular}

a Substrate: $\mathrm{H}_{2} \mathrm{O}_{2}$ mole ratio.

b Reaction conditions: BzOH $5 \mathrm{mmol}$, 1-hexanol $5 \mathrm{mmol}, \mathrm{H}_{2} \mathrm{O}_{2} 0.015$ mol.

It should be noted that under these reaction conditions, various secondary alcohols were oxidized to their corresponding ketones in fair yields (Table 3, entries 15-21, 23, 25). To investigate the selectivity of this method, a mixture of 1-hexanol and $\mathrm{BzOH}$ was subjected to oxidation. BzH was produced with a yield of $85 \%$ and only $8 \%$ of 1 -hexanal was detected. Such selectivity is a useful practical achievement in the oxidation of alcohols.

Based on the observations, the typical mechanism proposed for ZPNi catalyzed oxidation of alcohols with $\mathrm{H}_{2} \mathrm{O}_{2}$ is given in Scheme 2. At first, the Ni Lewis acid site (on the surface of ZPNi) interacts with $\mathrm{H}_{2} \mathrm{O}_{2}$ to form (I) and then reacts with the alcohol to give an intermediate (II) that subsequently gives the corresponding carbonyl compound and regenerated active sites by two steps of dehydration. Hence, any steric hindrance around the hydroxyl group of alcohols, such as the presence of a substituent at the ortho position (Table 3 , entries $2,5,7,9$ ) or more hindered secondary alcohols (Table 3, entries 15-21), causes longer reaction time and lower yields. Almost similar behavior was previously reported $[26,50,52]$.

The reusability of the ZPNi catalyst was investigated under the optimum reaction conditions for the oxidation of alcohols, and the results are shown in Table 4. The elemental composition of the catalyst remained largely unchanged following its 8th run, although the amount of nickel in the catalyst was re-

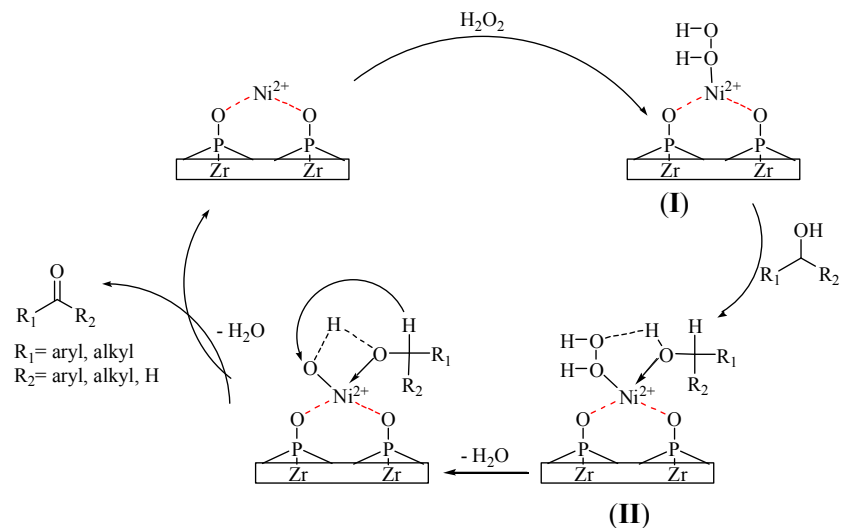

Scheme 2. Proposed mechanism for the $\mathrm{ZPNi} / \mathrm{H}_{2} \mathrm{O}_{2}$ catalytic system.

duced by almost 50\% compared with the first run (Table 1). The recycled ZPNi catalyst gave a similar product yield to the freshly prepared catalyst up until the sixth cycle.

All products were identified by comparing GC-MS (GC-Mass, Agilent 5975C) and 1H NMR spectra (Bruker-Avance AQS 400 $\mathrm{MHz}$ spectrometer; in $\mathrm{CDCl}_{3}$ ) with authentic samples $[23,28,47,49,51]$. ${ }^{1} \mathrm{H}$ NMR spectral data of some compounds from Table 3.

PhCHO (Table 3, entry 1): ${ }^{1} \mathrm{H}$ NMR (400 $\mathrm{MHz}^{\mathrm{CDCl}} 3$ ) $\delta=$ $10.01(\mathrm{~s}, 1 \mathrm{H}), 7.85-7.45(\mathrm{~m}, 5 \mathrm{H})$.

4-MeO- $\mathrm{C}_{6} \mathrm{H}_{4} \mathrm{CHO}$ (Table 3, entry 3): ${ }_{1} \mathrm{H}$ NMR $(400 \mathrm{MHz}$ $\left.\mathrm{CDCl}_{3}\right) \delta=9.90(1 \mathrm{H}, \mathrm{s}), 7.85(2 \mathrm{H}, \mathrm{d}, J=8.7 \mathrm{~Hz}), 7.0(2 \mathrm{H}, \mathrm{d}, J=8.7$ $\mathrm{Hz}), 3.93(3 \mathrm{H}, \mathrm{s})$.

4-Me- $\mathrm{C}_{6} \mathrm{H}_{4} \mathrm{CHO}$ (Table 3, entry 4): ${ }^{1} \mathrm{H}$ NMR (400 MHz, $\mathrm{CDCl}_{3}$ ) $\delta=9.92(\mathrm{~s}, 1 \mathrm{H}), 7.75(\mathrm{~d}, J=8.4 \mathrm{~Hz}, 2 \mathrm{H}), 7.32(\mathrm{~d}, J=8.4 \mathrm{~Hz}, 2 \mathrm{H})$, $2.43(\mathrm{~s}, 3 \mathrm{H})$.

2-Cl- $\mathrm{C}_{6} \mathrm{H}_{4} \mathrm{CHO}$ (Table 3, entry 5): ${ }^{1} \mathrm{H}$ NMR (400 MHz, $\mathrm{CDCl}_{3}$ ) $\delta=10.40(\mathrm{~s}, 1 \mathrm{H}), 7.88-7.86(\mathrm{q}, 1 \mathrm{H}), 7.54-7.31(\mathrm{~m}, 3 \mathrm{H})$.

4-NC- $\mathrm{C}_{6} \mathrm{H}_{4} \mathrm{CHO}$ (Table 3, entry 11 ) ${ }^{1} \mathrm{H}$ NMR $(400 \mathrm{MHz}$, $\left.\mathrm{CDCl}_{3}\right) \delta=10.13(\mathrm{~s}, 1 \mathrm{H}), 8.11(\mathrm{~d}, J=8.2 \mathrm{~Hz}, 2 \mathrm{H}), 7.90(\mathrm{~d}, J=8.2$ $\mathrm{Hz}, 2 \mathrm{H})$.

$\mathrm{Ph}_{2} \mathrm{CO}$ (Table 3, entry 15): ${ }^{1} \mathrm{H}$ NMR (400 MHz, $\left.\mathrm{CDCl}_{3}\right) \delta=$ $7.81(\mathrm{~d}, J=7.5 \mathrm{~Hz}, 4 \mathrm{H}), 7.59(\mathrm{t}, J=7.3 \mathrm{~Hz}, 2 \mathrm{H}), 7.49(\mathrm{t}, J=8.0 \mathrm{~Hz}$, $4 \mathrm{H})$.

$\mathrm{C}_{6} \mathrm{H}_{5} \mathrm{COCH}_{3}$ (Table 3, entry 16): ${ }^{1} \mathrm{H}$ NMR (400 MHz, $\left.\mathrm{CDCl}_{3}\right) \delta$ $=7.97(\mathrm{~d}, J=7.6 \mathrm{~Hz}, 2 \mathrm{H}), 7.57(\mathrm{t}, J=7.3 \mathrm{~Hz}, 1 \mathrm{H}), 7.47(\mathrm{t}, J=7.7$ $\mathrm{Hz}, 2 \mathrm{H}), 2.62$ (s, 3H).

4- $\mathrm{MeO}-\mathrm{C}_{6} \mathrm{H}_{4} \mathrm{COCH}_{3}$ (Table 3, entry 17): ${ }^{1} \mathrm{H}$ NMR (400 MHz, $\left.\mathrm{CDCl}_{3}\right) \delta=7.90(\mathrm{~d}, J=9.0 \mathrm{~Hz}, 2 \mathrm{H}), 6.9(\mathrm{~d}, J=9.0 \mathrm{~Hz}, 2 \mathrm{H}), 3.85(\mathrm{~s}$, $3 \mathrm{H}), 2.58$ (s, 3H).

Cyclohexanone (Table 3, entry 25): ${ }^{1} \mathrm{H}$ NMR (400 MHz, $\left.\mathrm{CDCl}_{3}\right) \delta=2.52-2.38(\mathrm{~m}, 4 \mathrm{H}), 2.2-1.64(\mathrm{~m}, 6 \mathrm{H})$.

A comparison of the catalytic efficiency of ZPNi with selected known catalysts is collected in Table 5 . $\mathrm{BzOH}$ was oxidized to $\mathrm{BzH}$ in less than $15 \mathrm{~min}$ at $50{ }^{\circ} \mathrm{C}$ with $90 \%$ isolated yield

\section{Table 4}

The catalyst reused under the optimum reaction conditions for oxidation of benzyl alcohol a.

Substrate Fresh run 1 run 2 run 3 run 4 run 5 run 6 run 7 run 8 \begin{tabular}{llllllllll}
\hline $\mathrm{BzOH}$ & 90 & 90 & 90 & 90 & 88 & 87 & 84 & 84 & 70
\end{tabular}

a Reaction conditions: $\mathrm{BzOH} 5 \mathrm{mmol}, \mathrm{H}_{2} \mathrm{O}_{2} 0.015 \mathrm{~mol}$, catalyst $0.5 \mathrm{~mol} \%$, $50{ }^{\circ} \mathrm{C}, 15 \mathrm{~min}$ 
Table 5

Comparison of protocols for oxidation of benzyl alcohol.

\begin{tabular}{|c|c|c|c|c|c|c|c|}
\hline $\begin{array}{l}\text { En- } \\
\text { try }\end{array}$ & Catalyst & $\begin{array}{c}\mathrm{T} \\
\left({ }^{\circ} \mathrm{C}\right)\end{array}$ & $\begin{array}{l}\text { Time } \\
(\mathrm{min})\end{array}$ & $\begin{array}{c}\mathrm{BzOH}: \mathrm{H}_{2} \mathrm{O}_{2} \\
\text { mole ratio }\end{array}$ & $\begin{array}{l}\text { Yield } \\
(\%)\end{array}$ & $\begin{array}{l}\text { Selectivi- } \\
\text { tya }(\%)\end{array}$ & [Ref.] \\
\hline 1 & $\mathrm{ZPCu}$ & 60 & 90 & $1: 3$ & 90 & $>99$ & [23] \\
\hline 2 & $\mathrm{CuSO}_{4}$ & 100 & 15 & $1: 3$ & 69 & 71 & [25] \\
\hline 3 & $\mathrm{ZnBr}_{2}$ & reflux & 90 & $1: 1^{b, c}$ & 96 & 100 & [27] \\
\hline 4 & TEMPO-IL/CuCl & 40 & 720 & $-^{d}$ & 55 & 100 & {$[30]$} \\
\hline 5 & $\mathrm{Ni}_{3}\left[\mathrm{Fe}(\mathrm{CN})_{6}\right]_{2}$ & 75 & 240 & $1: 3$ & $36^{\mathrm{e}}$ & 100 & {$[31]$} \\
\hline 6 & $\mathrm{Zn}_{4}\left(\mathrm{P}_{2} \mathrm{~W}_{15} \mathrm{O}_{56}\right)^{16-}$ & reflux & 45 & $1: 10^{c}$ & 94 & 100 & [35] \\
\hline 7 & $(\mathrm{TEAH}) \mathrm{H}_{2} \mathrm{PW}_{12} \mathrm{O}_{40}$ & 100 & 180 & 1:0.8 & $99.6^{\mathrm{e}}$ & 100 & [36] \\
\hline 8 & Zn-Co-LHD & 65 & 540 & $1: 5 \mathrm{c}, \mathrm{d}$ & $72 \mathrm{e}$ & 90 & [37] \\
\hline 9 & $\mathrm{H}_{4} \mathrm{SiW}_{12} \mathrm{O}_{40} / \mathrm{SiO}_{2}$ & r.t. & 240 & $-^{d}$ & $82^{c}$ & 100 & [39] \\
\hline 10 & $\begin{array}{c}\text { SF-3-APTS-Fe(TCl } \\
\text { PP) }\end{array}$ & r.t. & 180 & $1: 1^{c, d}$ & 99 & 100 & {$[45]$} \\
\hline 11 & $\mathrm{WO}_{4} @ \mathrm{PMO}-\mathrm{IL}$ & 90 & 720 & $1: 5^{c}$ & 75 e & 100 & {$[48]$} \\
\hline 12 & $\mathrm{Au} / \mathrm{UiO}-66$ & 80 & 1200 & $-^{\mathrm{d}}$ & 63.7 & 100 & [55] \\
\hline 13 & PSFC & r.t. & 7 & $1: 5^{c}$ & 93 & 100 & [56] \\
\hline 14 & $\mathrm{Au} / \mathrm{Al}_{2} \mathrm{O}_{3}$ & 100 & 15 & $-\mathrm{d}, \mathrm{g}$ & $45^{\mathrm{e}}$ & 86 & [57] \\
\hline 15 & $\mathrm{PMo}_{11} \mathrm{Co}$ & 90 & 1440 & $1: 3$ & 56.5 e & 90.9 & {$[58]$} \\
\hline 16 & Mn(salen)OAc & r.t. & 30 & $1: 2^{\mathrm{c}, \mathrm{h}}$ & 91 & 100 & [59] \\
\hline 17 & BPFC & 70 & 5 & $1: 1.5$ & 95 & 100 & [60] \\
\hline 18 & $\mathrm{ZPNi}$ & 50 & 15 & $1: 2$ & 90 & $>99$ & $\begin{array}{l}\text { This } \\
\text { work }\end{array}$ \\
\hline
\end{tabular}

a Selectivity for BzH.

b Chloramine-T as the oxidant.

${ }^{c} \mathrm{CH}_{3} \mathrm{CN}$ as solvent.

${ }^{\mathrm{d}}$ Atmospheric $\mathrm{O}_{2}$ as the oxidant.

e Conversion of $\mathrm{BzOH}$.

f TBHP as the oxidant.

$\mathrm{g}$ Toluene as solvent.

${ }^{\mathrm{h}} \mathrm{NaIO}_{4}$ as the oxidant.

using the present protocol (Table 5, entry 18). Although the reaction conditions are different, the catalyst used in this study (ZPNi) may be regarded as one of the better catalysts with regards to lower reaction time and temperatures, better $\mathrm{BzH}$ yields and selectivity toward BzH as the major product. The catalyst is also easily regenerated for further application.

\section{Conclusions}

In summary, we have reported the catalytic performance of water-insoluble ZPNi in the oxidation of alcohols using $\mathrm{H}_{2} \mathrm{O}_{2}$. The catalyst was characterized by various methods and the results showed good agreement with literature. ZPNi showed outstanding catalytic performance with excellent conversion of $\mathrm{BzOH}$ and selectivity to $\mathrm{BzH}$ at $50^{\circ} \mathrm{C}$ at $15 \mathrm{~min}$. The selectivity remained unchanged for all reactions, although the yields were found to be affected by steric hindrance. Alcohols having bulky groups required longer reaction time. The results clearly reveal that this method can be applied for chemoselective oxidation of $\mathrm{BzOHs}$ in the presence of aliphatic alcohols. This procedure is environmentally benign, applicable to a wide range of alcohols, efficient, high yielding, safe and operationally simple.

\section{Acknowledgments}

We gratefully acknowledge the funding support received for this project from the Isfahan University of Technology, IR Iran.

\section{References}

[1] Gan H M, Zhao X G, Song B N, Guo L, Zhang R, Chen C, Chen J Z, Zhu W W, Hou Z S. Chin J Catal (干慧媚, 赵秀阁, 宋宝宁, 郭立, 张然, 陈晨, 陈吉忠, 朱闻闻, 侯震山. 催化学报), 2014, 35: 1148

[2] Sun L Y, Boo W J, Sue H J, Clearfield A. New J Chem, 2007, 31: 39

[3] Hajipour A R, Karimi H. Mater Lett, 2014, 116: 356

[4] Pet'kov V I, Markin A V, Shchelokov I A, Sukhanov M V, Smirnova N N. Russ J Phys Chem, 2007, 81: 1728

[5] Shi Q S, Tan S Z, Ouyang Y S, Yang Q H, Chen A M, Li W R, Shu X L, Feng J, Fang J, Chen Y B. Adv Matter Res, 2011, 150-151: 852

[6] Cai X, Dai G J, Tan S Z, Ouyang Y, Ouyang Y S, Shi Q S. Mater Lett,

\section{Graphical Abstract}

Chin. J. Catal., 2015, 36: 1109-1116 doi: 10.1016/S1872-2067(14)60315-6

\section{Selective oxidation of alcohols over nickel zirconium phosphate}

Abdol R. Hajipour*, Hirbod Karimi, Afshin Koohi

Isfahan University of Technology, Iran;

University of Wisconsin, USA;

Islamic Azad University, Iran

Nickel zirconium phosphate was prepared and used as an efficient catalyst for the selective oxidation of various alcohols to the corresponding aldehydes and ketones, in good yields and with excellent selectivity.

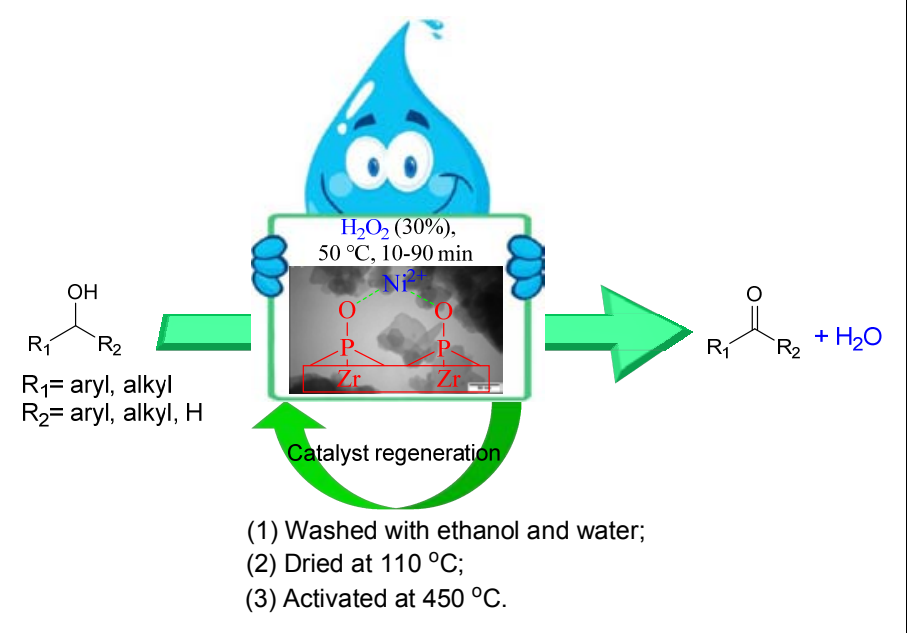


2012, 67: 199

[7] Wang Q, Yu J F, Liu J J, Guo Z H, Umar A, Sun L Y. Sci Adv Mater, 2013, 5: 469

[8] Allulli S, Ferragina C, La Ginestra A, Massucci M A, Tomassini N, Tomlinson A A G.J Chem Soc, Dalton Trans, 1976: 2115

[9] Shpeizer B, Poojary D M, Ahn K, Runyan C E Jr, Clearfield A. Science, 1994, 266: 1357

[10] Shpeizer B G, Sylvester P, Cahill R A, Clearfield A. Chem Mater, 1999, 11: 1201

[11] Giannoccaro P, Gargano M, Fanizzi A, Ferragina C, Aresta M. Appl Catal A, 2005, 284: 77

[12] Khare S, Chokhare R. J Mole Catal A, 2012, 353-354: 138

[13] Yang Y H, Dai G J, Tan S Z, Liu Y L, Shi Q S, Ouyang Y S. J Rare Earths, 2011, 29: 308

[14] Dai G J, Yu A L, Cai X, Shi Q S, Ouyang Y S, Tan S S. J Rare Earths, 2012, 30: 820

[15] Zhang Q R, Du W, Pan B C, Pan B J, Zhang W M, Zhang Q J, Xu Z W, Zhang Q X.J Hazard Mater, 2008, 152: 469

[16] Costantino U, Szirtes L, Kuzmann E, Megyeri J, Lázár K. Solid State Ionics, 2001, 141-142: 359

[17] Khare S, Chokhare R. J Mol Catal A, 2011, 344: 83

[18] Wang X Y, Hua W M, Yue Y H, Gao Z. Chem J Chin Univ (王雪燕, 华 伟明, 乐英红, 高滋. 高等学校化学学报), 2013, 34: 1913

[19] Gawande M B, Deshpande S S, Sonavane S U, Jayaram R V. J Mol Catal A, 2005, 241: 151

[20] Pylinina A I, Mikhalenko I I. Russ J Phys Chem A, 2013, 87: 372

[21] Pylinina A I, Mikhalenko I I. Russ J Phys Chem A, 2011, 85: 2109

[22] Hajipour A R, Karimi H, Karimzadeh M. Monatsh Chem, 2014, 145: 1461

[23] Hajipour A R, Karimi H. Chin J Catal (催化学报), 2014, 35: 1529

[24] Hajipour A R, Karimi H. Chin J Catal (催化学报), 2014, 35: 1982

[25] Ahmad J U, Räisänen M T, Leskelä M, Repo T. Appl Catal A, 2012, 411-412: 180

[26] Hu Z Z, Kerton F M. Appl Catal A, 2012, 413-414: 332

[27] Wang P, Cai J, Yang J B, Sun C L, Li L S, Hu H Y, Ji M. Tetrahedron Lett, 2013, 54: 533

[28] Lingaiah N, Reddy K M, Babu N S, Rao K N, Suryanarayana I, Prasad P S S. Catal Commun, 2006, 7: 245

[29] Rao P S N, Rao K T V, Sai Prasad P S, Lingaiah N. Chin J Catal (催化 学报), 2011, 32: 1719

[30] Liu L, Ji L Y, Wei Y Y. Monatsh Chem, 2008, 139: 901

[31] Ali S R, Chandra P, Latwal M, Jain S K, Bansal V K, Singh S P. Chin J Catal (催化学报), 2011, 32: 1844

[32] Zhang H, Liu Y, Zhang X G. Chin J Catal (张海, 刘英, 张勋高. 催化 学报), 2011, 32: 1693

[33] Zhang H, Fu L L, Zhong H M. Chin J Catal (张华, 付罗岭, 钟红敏. 催化学报), 2013, 34: 1848

[34] Zhou X T, Ji H B. Chin J Catal (周贤太, 纪红兵. 催化学报), 2012, 33: 1906

[35] Farsani M R, Jalilian F, Yadollahi B, Rudbari H A. Polyhedron, 2014, 76: 102
[36] Su H, Yang C. Chin J Catal (苏浩, 杨春. 催化学报), 2014, 35: 1224

[37] Zou X X, Goswami A, Asefa T. J Am Chem Soc, 2013, 135: 17242

[38] Zhou C L, Liu Y. Chin J Catal (周成亮, 刘晔. 催化学报), 2010, 31: 656

[39] Farhadi S, Babazadeh Z, Maleki M. Acta Chim Slov, 2006, 53: 72

[40] Villa A, E-chan-thaw C, Schiavoni M, Campisi S, Wang D, Prati L. Chin J Catal (催化学报), 2014, 35: 945

[41] Yang K H. Acta Chim Slov, 2014, 61: 629

[42] Ma L, Jia L H, Guo X F, Xiang L J. Chin J Catal (马良, 贾丽华, 郭祥 峰, 项礼军. 催化学报), 2014, 35: 108

[43] Azarifar D, Najminejad Z, Khosravi K. J Iran Chem Soc, 2013, 10: 979

[44] Chatel G, Monnier C, Kardos N, Voiron C, Andrioletti B, Draye M. Appl Catal A, 2014, 478: 157

[45] Rahimi R, Ghoreishi S Z, Dekamin M G. Monatsh Chem, 2012, 143: 1031

[46] Shaabani A, Farhangi E, Rahmati A. Monatsh Chem, 2008, 139: 905

[47] Moriyama K, Takemura M, Togo H.J Org Chem, 2014, 79: 6094

[48] Karimi B, Rostami F B, Khorasani M, Elhamifar D, Vali H. Tetrahedron, 2014, 70: 6114

[49] Liu X L, Xia Q Q, Zhang Y J, Chen C Y, Chen W Z.J Org Chem, 2013, 78: 8531

[50] Babu S G, Priyadarsini P A, Karvembu R. Appl Catal A, 2011, 392: 218

[51] Wang J M, Yan L, Qian G, Li S Q, Yang K L, Liu H T, Wang X L. Tetrahedron, 2007, 63: 1826

[52] Chen C Y, Liu B, Chen W Z. Synthesis, 2013, 45: 3387

[53] Mojtahedi M M, Saidi M R, Bolourtchian M, Shirzi J S. Monatsh Chem, 2001, 132: 655

[54] Zolfigol M A, Hajjami M, Ghorbani-Choghamarani A.J Iran Chem Soc, 2012, 9: 13

[55] Zhu J, Wang P C, Lu M. Appl Catal A, 2014, 477: 125

[56] Bekhradnia A R, Zahir F, Arshadi S. Monatsh Chem, 2008, 139: 521

[57] Rautiainen S, Simakova O, Guo H F, Leino A R, Kordás K, Murzin D, Leskelä M, Repo T. Appl Catal A, 2014, 485: 202

[58] Pathan S, Patel A. Appl Catal A, 2013, 459: 59

[59] Bahramian B, Mirkhani V, Moghadam M, Amin A H. Appl Catal A, 2006, 315: 52

[60] Özgün B, Yaylaoglu A, Şendil K. Monatsh Chem, 2007, 138: 161

[61] Lou J D, Gao C L, Li L, Fang Z G. Monatsh Chem, 2006, 137: 1071

[62] Tangestaninejad S, Moghadam M, Mirkhani V, Mohammadpoor-Baltork I, Hoseini N. J Iran Chem Soc, 2010, 7: 663

[63] Ghorbani-Choghamarani A, Azadi G.J Iran Chem Soc, 2011, 8: 1082

[64] Hajipour A R, Karimi H. Appl Catal A, 2014, 482: 99

[65] Hajipour A R, Karimi H. Chin J Catal (催化学报), 2014, 35: 1136

[66] Sneddon J. Biochem Pharmacol, 1987, 36: 3723

[67] Birkholz M, Rudert R. Phys Status Solid B, 2008, 245: 1858

[68] Sing K S W, Everett D H, Haul R A W, Moscou L, Pierotti R A, Rouquerol J, Siemieniewska T. Pure Appl Chem, 1985, 57: 603

[69] Corma A. Chem Rev, 1995, 95: 559

[70] Tyagi B, Chudasama C D, Jasra R V. Appl Clay Sci, 2006, 31: 16 